\title{
Editorial
}

\section{Novos tempos para nossa jovem Tempus}

A Revista Tempus Actas em Saúde Coletiva chega ao final de 2014 com muitos motivos para comemorar, muitas foram as vitórias, entre elas, o lançamento dos seus dois últimos números do ano. Ao lançarmos os Números 3 e 4, o primeiro nesta semana e o segundo na próxima, trazemos uma nova formatação visual, normativa e editorial, segundo as exigências da base de dados LILACS - Literatura Latino-Americana e do Caribe em Ciências da Saúde, um dos mais expressivosindexadoresda América Latina e Caribe.Isso mesmo, fomos avaliados positivamente e estamos a um passo de mais uma importante indexação para nosso periódico científico.

Por sermos poucos voluntários abnegados para com a criação e manutenção da Tempus Actas, a equipe editorial assumiu a responsabilidade pelo pequeno atraso de nossa terceira edição do final de setembro, lançada agora, para rever todo o acervo da Tempus, desde sua criação em fins de 2006 aos dias atuais, bem como ajustarmos os mais recentes artigos aprovados deste número que ora chega com os votos de um Feliz Natal a todos os que tem acreditado na Revista Tempus.

As comemorações não param por ai. Este ano destacamos duas produções especiais, a primeira destinada à comunidade indígena e a segunda, aos povos do campo e floresta. Esta última em parceria com a Universidade de Coimbra, tendo como coeditor do número temático, o professor Boaventura de Sousa Santos, que, ao lado do pesquisador Fernando Carneiro e Noemi Krefta, representando o Grupo da Terra, trouxeram um novo formato de revisão de pares, estabelecendo um diálogo entre a academia e a sociedade.

Este número, por sua vez, não poderia ser diferente. Ainda no ritmo da internacionalização do periódico, trazemos como destaque o texto da professora Lise Renaud, do Centro de Pesquisa em Comunicação em Saúde, da Universidade do Quebec em Montreal (ComSanté/UQÁM), que escrevem sobre Comunicação em Saúde, assim como outros autores que contribuem para estabelecermos uma discussão sobre esse tema em evidência.

Devido ao grande volume de submissões livres recebidas pela Tempus nos últimos anos, percebemos que apenas um número livre não estava dando vazão aos artigos já aprovados, assim, em atenção aos autores que nos submetem suas produções decidimos publicar outros artigos fora do tema destaque, compondo assim um novo formato editorial onde o tema principal segue em maior proporção, acompanhado de outros artigos de tema livre. Assim, além 
$10 / /$

de acompanharmos as tendências dos periódicos já consolidados no campo da comunicação científica, trazemos um número atual e que contribui para um diálogo ainda maior entre autores e grupos de pesquisa no Brasil e no exterior. Boa leitura!

Ana Valéria M. Mendonça

Júlio César Cabral

RackynellyAlves Sarmento Soares

Maria Fátima de Sousa 